\title{
Evaluation of Phenolics and Antioxidant Enzyme Systems for Phytophthora Blight in Resistant and Susceptible Variety of Sesame (Sesamum indicum L.)
}

\author{
D.S. Mori", U.K. Kandoliya, V.S. Bhatt, S.V. Patel and B.A. Golakiya \\ Department of Biotechnology, College of agriculture, Junagadh Agricultural University, \\ Junagadh, Gujarat, India \\ *Corresponding author
}

A B S T R A C T

\begin{tabular}{|l|}
\hline K e y w o r d s \\
Sesame, Phytophthora \\
blight, Superoxide \\
dismutase (SOD), \\
Guaiacol peroxidase \\
(GPX), Ascorbate \\
peroxidase (APX), \\
Catalase (CAT). \\
\hline Article Info \\
\hline $\begin{array}{l}\text { Accepted: } \\
\text { 21 June } 2017 \\
\text { Available Online: } \\
\text { 10 August } 2017\end{array}$ \\
\hline
\end{tabular}

The present experiment was conducted with an objective to evaluate changes in total phenol and antioxidant enzymes in resistance and susceptible cultivars of sesames against Phytophthora blight. Among the sesame cultivars, root of resistant cultivar G. Til-10 showed the highest amount of total phenol content $\left(0.846 \mathrm{mg} \cdot \mathrm{g}^{-1} \mathrm{Fr}\right.$.Wt. $)$, while infected

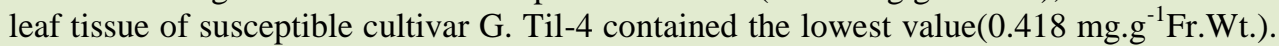
The activity of ROS scavenging enzymes superoxide dismutase (SOD), Guaiacol peroxidase (GPX), Ascorbate peroxidase (APX) and catalase (CAT) was remained higher in infected root and leaf tissue of the susceptible cultivar G. Til-4 compared to resistant genotypes. The activity of superoxide dismutase was increased an average 1-2 fold in susceptible genotype from pre-infection to infection stage. In case of GPX activity the activity continuously increased in infected tissue from pre-infection to post-infection stage with respect to non-infected tissue. The higher activity was recorded in susceptible cultivar G. Til-4. Same trend of result observed in ascorbate peroxidase activity. In case of polyphenol oxidase, highest activity was noted in infected leaf and root tissue of susceptible (G. Til-4) cultivar. The activity of catalase showed increased in activity of infected tissue compared to non-infected.

\section{Introduction}

The sesame belongs to the family Pedaliaceae and genus Sesamum is a selfpollinated annual herb with a basic chromosome number of $2 n=26$. Sesame has important agricultural attributes: it is adapted to tropical and temperate conditions, grows well on stored soil moisture with minimal irrigation or rainfall can produce good yields under high temperatures, and its seed has a high nutritional value (Bennet, 2011).

It is also grown in all the crop growing seasons viz, kharif, late kharif, rabi and summer. It is grown in more than one season in some part and in different seasons in other parts of the country. The main reason for low productivity in sesame is the adverse ecologies in which it is cropped and its vulnerability to abiotic and biotic stresses. Phytophthora blight is one of the biotic factors which adversely affect crops productivity of sesame. The differential reaction related to total phenol content and antioxidative enzymes for resistance and susceptible cultivars were observed when infected with pathogen. Thus the present experiment was planned to evaluate changes in total phenol and antioxidant enzymes in resistance and susceptible cultivars of sesames against Phytophthora blight. 


\section{Materials and Methods}

Earthen pots (Approximately $18 \mathrm{~cm}$ diameter) were used for pot culture studies. Pots were sterilized with 5 per cent formaldehyde solution.

Field soil with farm yard manure (FYM) and sand were mixed in the proportion of 1:2 and sterilized in autoclave at $1: 036 \mathrm{~kg} / \mathrm{cm}^{2}$ for one hour for three consecutive days. Previously incubated flask with Phytophthora pathogen was then added to the soil in the proportion of 1:10 (inoculums and sterilized soil).

\section{Diseases incidence}

Diseases incidence of sesame cultivars were measured under pathogen infested soil culture.

Earthen pots were used for preparation of pathogen inoculum of approximately $4 \times 10^{5}$ $\mathrm{cfu}^{-1}$ was mixed with soil three days prior to seed sowing.

Percentage of diseases incidence was recorded at different time interval based on pathogen infection on seedling (Akter et al., 2007).

Percent (\%)

No. of disease plants

Disease incidence $=$

Total No. of plants

\section{Stage of infection (Sampling interval)}

Sesame root and leaf tissues were collected at different stages of disease development. Different stages of infection were categorized as discussed by Dubey et al., (2011).

The days after sowing corresponding to the stage of disease along with disease symptoms are given below.

\section{Antioxidant enzyme assay}

\section{Sample extraction}

Extract for determination of superoxide dismutase (SOD), guaiacol peroxidase (GPX), ascorbate peroxidase (APX), Polyphenol oxidase (PPO) and catalase (CAT), activities were prepared from $0.5 \mathrm{~g}$ of leaves and $0.3 \mathrm{~g}$ root tissue homogenized with a pre-chilled mortar and pestle under ice cold condition in $2 \mathrm{ml}$ and $1 \mathrm{ml}$ of extraction buffer respectively, containing $50 \mathrm{mM}$ sodium phosphate buffer ( $\mathrm{pH}$ 7.4). The homogenates were centrifuged at $10,000 \mathrm{rpm}$ for 20 minutes and the supernatant was used for the assay.

\section{Superoxide dismutase (SOD)}

Total SOD (EC 1.15.1.1) activity was measured spectrophotometrically based on inhibition in the photochemical reduction of nitroblue tetrazoilum (NBT). The $3 \mathrm{ml}$ reaction mixture contained $50 \mathrm{mM}$ sodium phosphate buffer ( $\mathrm{pH} 7.8) 13 \mathrm{mM}$ methionine, $75 \mu \mathrm{M}$ NBT, $2 \mu \mathrm{M}$ riboflavin, $0.1 \mathrm{mM}$ EDTA and $0.05 \mathrm{ml}$ enzyme extract, riboflavin was added last (Van Rossun et al., 1997).

Test tubes were shaken and placed $30 \mathrm{~cm}$ below from a light blank consisting of four $15-\mathrm{w}$ fluorescent lamps. The reaction was allowed to run for 10 minutes and stopped by switching the light off.

The photoreduction in NBT was measured as increase in absorbance at $560 \mathrm{~nm}$. Blanks and controls were run the same way but without illumination and enzyme, respectively. One unit of SOD was defined as the quantity of enzyme required to inhibit the reduction of NBT by $50 \%$ in a reaction mixture. Enzyme unit of SOD was calculated according to formula given by (Constantine and Stanley, 1977). 


\section{Guaiacol peroxidase (GPX)}

GPX (EC 1.11.1.7) activity was determined in the homogenates by measuring the increase in absorption at $470 \mathrm{~nm}$ due to the formation of tetraguaiacol $\left(\varepsilon=26.6 \mathrm{mM}^{-1} \mathrm{~cm}^{-1}\right)$ in a reaction mixture containing $50 \mathrm{mM}$ sodium phosphate buffer $\mathrm{pH}$ 7.0, 0.1 mM EDTA, 25 $\mu \mathrm{l}$ enzyme extract, $10 \mathrm{mM}$ guaiacol and 10 $\mathrm{mM} \mathrm{H}_{2} \mathrm{O}_{2}$ (Costa et al., 2002).

\section{Ascorbate peroxidase (APX)}

APX (EC 1.11.1.11) activity was measured immediately in fresh extract and was assayed as described by Nakano and Asada (1981). 3 $\mathrm{ml}$ reaction mixture containing $50 \mathrm{mM}$ sodium phosphate buffer $\mathrm{pH} 7.0,0.1 \mathrm{mM}$ $\mathrm{H}_{2} \mathrm{O}_{2}, 0.5 \mathrm{mM}$ ascorbic acid, $0.1 \mathrm{mM}$ EDTA and $0.1 \mathrm{ml}$ enzyme extract. The hydrogen peroxide dependent oxidation of ascorbate was followed by a decrease in the absorbance at $290 \mathrm{~nm}\left(\varepsilon=2.8 \mathrm{mM}^{-1} \mathrm{~cm}^{-1}\right)$.

\section{Polyphenol oxidase (PPO)}

The PPO (EC 1.14.18.1) activity was measured using reaction mixture contained $2.9 \mathrm{ml}$ of catechol $(10 \mathrm{mM}$ catechol in $10 \mathrm{mM}$ phosphate buffer, $\mathrm{pH} 6.5$ and reaction was initiated by the addition of $100 \mu \mathrm{l}$ of enzyme extract. The changes in the colour due to the oxidized catechol were read at $490 \mathrm{~nm}$ for one minute at an interval of 15 second. Blank was carried out without substrate. The enzyme activity was expressed U.mg ${ }^{-1}$ protein and unit activity was defined as $\Delta$ OD.min. ${ }^{-1}$ g. ${ }^{-1}$ Fr.Wt. tissues (Malik and Singh, 1980).

\section{Results and Discussion}

\section{Percent disease incidence}

The sesame cultivars were grown in normal condition and blight sick condition. The percent disease incidence was based on blight symptoms of sesame plants at up to 24 days after sowing (DAS) in a plot was recorded and showed statistically significant differences. The value in percent showed the tolerance or susceptibility towards disease incidence (Table 1).

The percent disease incidence was significantly varied from $4.46 \%$ to $99.84 \%$ with the advancement of disease (Table 1). The cultivars G. Til-10 showed less disease incidence $(40.12 \%)$ at post-infection stage (24 DAS), which was indicating tolerance to blight. The disease incidence was significantly increased to the tune of $15.60 \%$ to $99.84 \%$ in which G. Til-4 showed at postinfection stage (24 DAS).

\section{Total phenol content}

Total phenol content in root and leaf tissues of two cultivars grown in both normal (healthy) pot and from sick pot (diseased plants) obtained at three (S1, S2 and S3) disease development stages were recorded (Table 2). Among the different disease stages, phenol content significantly varied from 0.216 to $0.846 \mathrm{mg} \cdot \mathrm{g}^{-1}$ Fr.Wt. The phenol content significantly increased as development of different disease stages, from pre-infection to post-infection (S1 to S3). The root and leaf tissues obtained from infected plants revealed higher amount of total phenol content as compared to tissue in control plants. The mean effect of root tissue of resistance G. Til-10 was found highest (0.676 mg. $\mathrm{g}^{-1}$ Fr. Wt.) and lowest phenol content was observed in leaf tissue of susceptible cultivar G. Til-4 (0.310 mg. ${ }^{-1}$ Fr. Wt. $)$.

Irrespective of stages, infected root tissue of resistant G. Til-10 cultivar showed 1.42 fold increased in phenol content as compared to pre-infection stage. The minimal phenol content $\left(0.216 \mathrm{mg.g}^{-1} \mathrm{Fr}\right.$. Wt. $)$ was examined in leaf tissue of susceptible G. Til-4 at all 
three stages of disease development. The combined effect of genotypes and disease development stages showed significant differences. Among both cultivars, infected root tissue of resistant cultivar G. Til-10 (0.846 mg.g ${ }^{-1}$ Fr. Wt.) showed highest phenol content, compared with infected leaf tissue of G. Til-10 (0.699 mg.g ${ }^{-1}$ Fr. Wt.).

Sharma et al., (2011) studied the metabolic alterations in Sesamum after infection with Macrophomina phaseolina and Fusarium oxysporum. This accomplished individually by the levels of total phenolic compounds of one week old plants. In infected plants polyphenols along with salicylic acid (SA) considerably exceeded when compared to control plants.

Patel et al., (2015) also reported the induction of phenol content in response to wilt pathogen infestation in pegionpea crop. Kandoliya and Vakharia (2013) also observe the higher phenol content in resistant variety of chickpea compared to susceptible variety in normal and infected plants of chickpea. This revealed inherent character of variety to cope with infection process.

\section{Superoxide dismutase (SOD)}

Superoxide dismutase (SOD) activity was examined in root and leaf tissue of resistant and susceptible cultivar of sesame. Irrespective of disease development stages, mean effect of resistant cultivars of sesame showed significant difference (Table 3 ).

The mean SOD avtivity was found higher in root tissue of susceptible G. Til-4 (34.508 U.mg $^{-1}$ Fr.Wt.) cultivar followed by root tissue of resistant G. Til-10 (33.283 U.mg ${ }^{-1}$ Fr.Wt.) cultivar). Among these cultivars, susceptible G. Til-4 (51.333 U.mg ${ }^{-1}$ Fr.Wt.) cultivar showed highest activity at infection stage (S2). During stage of post-infection (S3) infected root tissue of resistant G. Til-10 cultivar showed 1.55 fold highest activity compared to non-infected and 1.53 fold highest activity compared to $\mathrm{S} 1$ stage. In infected root tissue of susceptible root tissue of G. Til-4 cultivar showed 1.18 fold higher activity compared to non-infected. Overall, Superoxide dismutase activity increased at S1 to S3 stage of disease development in resistant cultivar was found, whereas in susceptible cultivar there were slight decline in activity was found. SOD activity of infected root tissues were increased fast as compared to infected leaf tissues. Rajab et al., (2009) examined the sesamum - Fusarium culture exudates interaction was accompanied by substantial increase in oxidative stress, probably as direct consequences of a progressive decline in the enzymatic system responsible for catabolism of active oxygen species. On the basis of quantitative data, among the enzymes tested, changes in SOD activity seemed to be related with the interaction of Sesamum $\times$ Fusarium.

Stage of infection (Sampling interval)

\begin{tabular}{|c|c|c|c|}
\hline Factor & Stage of disease & $\begin{array}{c}\text { Days after } \\
\text { sowing (DAS) }\end{array}$ & $\begin{array}{c}\text { Visible symptoms of treatments grown in } \\
\text { different pots }\end{array}$ \\
\hline $\mathbf{S}_{\mathbf{1}}$ & $\begin{array}{l}\text { Pre-inflectional } \\
\text { stage }\end{array}$ & 10 & $\begin{array}{l}\text { Normal, leaves were healthy and green in all } \\
\text { treatments }\end{array}$ \\
\hline $\mathbf{S}_{\mathbf{2}}$ & $\begin{array}{c}\text { Disease } \\
\text { inflectional stage }\end{array}$ & 17 & Brown spots on leaves in some of treatments. \\
\hline $\mathbf{S}_{\mathbf{3}}$ & $\begin{array}{l}\text { Post inflectional } \\
\text { stage }\end{array}$ & 22 & $\begin{array}{c}\text { Leaves shriveled and root gets brown, } \\
\text { drooping of whole plants but not in all } \\
\text { treatments. }\end{array}$ \\
\hline
\end{tabular}


Table.1 Percent (\%) disease incidence at different growth periods (DAS) of seedlings

\begin{tabular}{|c|c|c|c|c|c|c|c|c|c|c|}
\hline \multirow{2}{*}{$\begin{array}{c}\text { Sr. } \\
\text { No. }\end{array}$} & \multirow{2}{*}{ Cultivars } & \multicolumn{10}{|c|}{\begin{tabular}{c}
$\mathbf{1 6}$ \\
\cline { 3 - 11 }
\end{tabular}} & & $\mathbf{1 7}$ & $\mathbf{1 8}$ & $\mathbf{1 9}$ & $\mathbf{2 0}$ & $\mathbf{2 1}$ & $\mathbf{2 2}$ & $\mathbf{2 3}$ & $\mathbf{2 4}$ \\
& & DAS & DAS & DAS & DAS & DAS & DAS & DAS & DAS & DAS \\
\hline 1 & G. Til-10 & 4.46 & 19.72 & 20.30 & 29.57 & 29.42 & 32.60 & 33.40 & 35.78 & 40.12 \\
\hline 2 & G. Til-4 & 15.60 & 21.75 & 35.37 & 47.56 & 55.36 & 61.23 & 72.42 & 89.50 & 99.84 \\
\hline
\end{tabular}

Table.2 Total phenol content (mg.g ${ }^{-1}$ Fr. Wt.) of sesame cultivars at three different disease stages

\begin{tabular}{|c|c|c|c|c|c|c|c|c|}
\hline \multirow{2}{*}{$\begin{array}{l}\text { Sr. } \\
\text { No. }\end{array}$} & \multirow[t]{2}{*}{ Variety } & \multicolumn{2}{|c|}{ Stage- 1} & \multicolumn{2}{|c|}{ Stage- 2} & \multicolumn{2}{|c|}{ Stage- 3} & \multirow{2}{*}{$\begin{array}{c}\text { Mean } \\
(\mathbf{V x})\end{array}$} \\
\hline & & $\begin{array}{c}\text { Non } \\
\text { Infected }\end{array}$ & Infected & $\begin{array}{c}\text { Non } \\
\text { Infected }\end{array}$ & Infected & $\begin{array}{c}\text { Non } \\
\text { Infected }\end{array}$ & Infected & \\
\hline 1 & $\begin{array}{c}\text { G.Til-10 } \\
\text { root }\end{array}$ & 0.515 & 0.592 & 0.657 & 0.752 & 0.693 & 0.846 & 0.676 \\
\hline 2 & $\begin{array}{c}\text { G.Till-10 } \\
\text { leaf }\end{array}$ & 0.430 & 0.490 & 0.513 & 0.590 & 0.556 & 0.699 & 0.546 \\
\hline 3 & $\begin{array}{c}\text { G.Till-4 } \\
\text { root }\end{array}$ & 0.279 & 0.322 & 0.479 & 0.481 & 0.393 & 0.515 & 0.412 \\
\hline \multirow[t]{2}{*}{4} & $\begin{array}{c}\text { G.Till-4 } \\
\text { leaf }\end{array}$ & 0.216 & 0.297 & 0.276 & 0.351 & 0.301 & 0.418 & 0.310 \\
\hline & $\begin{array}{c}\text { Mean } \\
(\mathbf{S x})\end{array}$ & 0.360 & 0.425 & 0.481 & 0.544 & 0.486 & 0.620 & \\
\hline & & \multicolumn{3}{|c|}{ S.Em \pm} & \multicolumn{2}{|c|}{ CD at $5 \%$} & \multicolumn{2}{|c|}{ CV \% } \\
\hline & $\mathbf{V x}$ & \multicolumn{3}{|c|}{0.0025} & \multicolumn{2}{|c|}{0.0071} & \multirow{3}{*}{\multicolumn{2}{|c|}{2.17}} \\
\hline & $\mathbf{S x}$ & \multicolumn{3}{|c|}{0.003} & \multicolumn{2}{|c|}{0.0085} & & \\
\hline \multicolumn{2}{|c|}{$\mathbf{V x} \times \mathrm{Sx}$} & \multicolumn{3}{|c|}{0.0061} & \multicolumn{2}{|c|}{0.0174} & & \\
\hline
\end{tabular}

Table.3 Superoxide dismutase activity $\left(\mathrm{U} \cdot \mathrm{mg}^{-1}\right.$ Fr. Wt.) at different disease development stages of Phytophthora blight in sesamum

\begin{tabular}{|c|c|c|c|c|c|c|c|c|}
\hline \multirow{2}{*}{$\begin{array}{l}\text { Sr. } \\
\text { No. }\end{array}$} & \multirow[t]{2}{*}{ Variety } & \multicolumn{2}{|c|}{ Stage- 1} & \multicolumn{2}{|c|}{ Stage- 2} & \multicolumn{2}{|c|}{ Stage- 3} & \multirow{2}{*}{$\begin{array}{c}\text { Mean } \\
(\mathbf{V x})\end{array}$} \\
\hline & & $\begin{array}{c}\text { Non } \\
\text { Infected }\end{array}$ & Infected & $\begin{array}{c}\text { Non } \\
\text { Infected }\end{array}$ & Infected & $\begin{array}{c}\text { Non } \\
\text { Infected }\end{array}$ & Infected & \\
\hline 1 & $\begin{array}{l}\text { G.Til-10 } \\
\text { root }\end{array}$ & 26.323 & 27.453 & 36.443 & 40.153 & 27.083 & 42.243 & 33.283 \\
\hline 2 & $\begin{array}{c}\text { G.Til-10 } \\
\text { leaf }\end{array}$ & 16.043 & 22.433 & 32.903 & 36.863 & 38.503 & 39.943 & 31.115 \\
\hline 3 & $\begin{array}{c}\text { G.Til-4 } \\
\text { root } \\
\end{array}$ & 21.833 & 44.463 & 33.143 & 51.333 & 25.723 & 30.553 & 34.508 \\
\hline \multirow[t]{2}{*}{4} & $\begin{array}{c}\text { G.Til-4 } \\
\text { leaf }\end{array}$ & 30.467 & 39.323 & 31.133 & 46.803 & 28.023 & 28.583 & 34.056 \\
\hline & \multirow[t]{2}{*}{$\begin{array}{c}\text { Mean } \\
(\mathbf{S x})\end{array}$} & 23.667 & 33.418 & 33.406 & 43.788 & 29.833 & 35.331 & \\
\hline & & \multicolumn{3}{|c|}{ S.Em \pm} & \multicolumn{2}{|c|}{ CD at $5 \%$} & \multicolumn{2}{|c|}{ CV \% } \\
\hline & $\mathbf{V x}$ & \multicolumn{3}{|c|}{0.3795} & \multicolumn{2}{|c|}{1.0802} & \multirow{3}{*}{\multicolumn{2}{|c|}{4.84}} \\
\hline & $\mathbf{S x}$ & \multicolumn{3}{|c|}{0.4648} & \multicolumn{2}{|c|}{1.3229} & & \\
\hline & $\mathrm{X} \mathrm{Sx}$ & \multicolumn{3}{|c|}{0.9295} & \multicolumn{2}{|c|}{2.6456} & & \\
\hline
\end{tabular}

$\mathrm{U}=\Delta$ OD. $\mathrm{min}^{-1} \cdot \mathrm{ml}^{-1}$ 
Table.4 Guaiacol peroxidase activity (U.mg ${ }^{-1}$ Fr. Wt.) at different disease development stages of Phytophthora blight in sesame

\begin{tabular}{|c|c|c|c|c|c|c|c|c|}
\hline \multirow{2}{*}{$\begin{array}{l}\text { Sr. } \\
\text { No. }\end{array}$} & \multirow[t]{2}{*}{ Variety } & \multicolumn{2}{|c|}{ Stage- 1} & \multicolumn{2}{|c|}{ Stage- 2} & \multicolumn{2}{|c|}{ Stage- 3} & \multirow{2}{*}{$\begin{array}{c}\text { Mean } \\
(\mathbf{V x})\end{array}$} \\
\hline & & $\begin{array}{c}\text { Non } \\
\text { Infected }\end{array}$ & Infected & $\begin{array}{c}\text { Non } \\
\text { Infected }\end{array}$ & Infected & $\begin{array}{c}\text { Non } \\
\text { Infected }\end{array}$ & Infected & \\
\hline 1 & $\begin{array}{c}\text { G.Til-10 } \\
\text { root }\end{array}$ & 85.460 & 101.740 & 102.110 & 109.230 & 118.850 & 171.120 & 114.752 \\
\hline 2 & $\begin{array}{c}\text { G.Till-10 } \\
\text { leaf }\end{array}$ & 85.380 & 90.610 & 95.120 & 108.990 & 107.490 & 140.790 & 104.730 \\
\hline 3 & $\begin{array}{c}\text { G.Till-4 } \\
\text { root }\end{array}$ & 92.920 & 97.430 & 101.340 & 124.730 & 150.440 & 189.460 & 126.053 \\
\hline \multirow[t]{2}{*}{4} & $\begin{array}{c}\text { G.Till-4 } \\
\text { leaf }\end{array}$ & 72.240 & 77.480 & 128.780 & 148.970 & 189.010 & 211.750 & 138.038 \\
\hline & \multirow[t]{2}{*}{$\begin{array}{c}\text { Mean } \\
(\mathbf{S x})\end{array}$} & 84.000 & 91.815 & 106.838 & 122.980 & 141.448 & 178.280 & \\
\hline & & \multicolumn{3}{|c|}{ S.Em \pm} & \multicolumn{2}{|c|}{ CD at $5 \%$} & \multicolumn{2}{|c|}{ CV \% } \\
\hline \multicolumn{2}{|r|}{$\mathbf{V x}$} & \multicolumn{3}{|c|}{0.7095} & \multicolumn{2}{|c|}{2.0194} & \multirow{3}{*}{\multicolumn{2}{|c|}{2.49}} \\
\hline & & \multicolumn{3}{|c|}{0.869} & \multicolumn{2}{|c|}{2.4734} & & \\
\hline \multicolumn{2}{|c|}{$\frac{D x}{V x} \mathbf{X x}$} & \multicolumn{3}{|c|}{1.7379} & \multicolumn{2}{|c|}{4.9465} & & \\
\hline
\end{tabular}

Table.5 Ascorbate peroxidase activity (U.mg ${ }^{-1}$ Fr. Wt.) at different disease development stages of Phytophthora blight in sesamum

\begin{tabular}{|c|c|c|c|c|c|c|c|c|}
\hline \multirow{2}{*}{$\begin{array}{l}\text { Sr. } \\
\text { No. }\end{array}$} & \multirow[t]{2}{*}{ Variety } & \multicolumn{2}{|c|}{ Stage- 1} & \multicolumn{2}{|c|}{ Stage- 2} & \multicolumn{2}{|c|}{ Stage- 3} & \multirow{2}{*}{$\begin{array}{c}\text { Mean } \\
(\mathbf{V x})\end{array}$} \\
\hline & & $\begin{array}{c}\text { Non } \\
\text { Infected }\end{array}$ & Infected & $\begin{array}{c}\text { Non } \\
\text { Infected }\end{array}$ & Infected & $\begin{array}{c}\text { Non } \\
\text { Infected }\end{array}$ & Infected & \\
\hline 1 & $\begin{array}{c}\text { G.Til } 10 \\
\text { root }\end{array}$ & 2.013 & 2.573 & 3.773 & 7.933 & 3.853 & 9.453 & 4.933 \\
\hline 2 & $\begin{array}{l}\text { G.Till- } \\
10 \text { leaf }\end{array}$ & 1.733 & 2.073 & 2.773 & 4.543 & 3.233 & 6.433 & 3.465 \\
\hline 3 & $\begin{array}{c}\text { G.Till-4 } \\
\text { root }\end{array}$ & 4.173 & 7.853 & 12.653 & 14.413 & 17.133 & 22.183 & 13.068 \\
\hline \multirow[t]{2}{*}{4} & $\begin{array}{l}\text { G.Till-4 } \\
\text { leaf }\end{array}$ & 3.073 & 4.043 & 9.583 & 11.993 & 14.143 & 19.283 & 10.353 \\
\hline & \multirow[t]{2}{*}{$\begin{array}{c}\text { Mean } \\
(\mathbf{S x})\end{array}$} & 2.748 & 4.136 & 7.196 & 9.721 & 9.591 & 14.338 & \\
\hline & & \multicolumn{3}{|c|}{ S.Em \pm} & \multicolumn{2}{|c|}{ CD at $5 \%$} & \multicolumn{2}{|c|}{ CV \% } \\
\hline \multicolumn{2}{|r|}{$\mathbf{V x}$} & \multicolumn{3}{|c|}{0.0472} & \multicolumn{2}{|c|}{0.1343} & \multirow{3}{*}{\multicolumn{2}{|c|}{2.52}} \\
\hline & Sx & \multicolumn{3}{|c|}{0.0578} & \multicolumn{2}{|c|}{0.1645} & & \\
\hline \multicolumn{2}{|c|}{ Vx X Sx } & \multicolumn{3}{|c|}{0.1157} & \multicolumn{2}{|c|}{0.3293} & & \\
\hline
\end{tabular}


Table.6 Polyphenol oxidase activity (U.mg ${ }^{-1}$ Fr. Wt.) at different disease development stages of Phytophthora blight in sesamum

\begin{tabular}{|c|c|c|c|c|c|c|c|c|}
\hline \multirow{2}{*}{$\begin{array}{l}\text { Sr. } \\
\text { No. }\end{array}$} & \multirow[t]{2}{*}{ Variety } & \multicolumn{2}{|c|}{ Stage- 1} & \multicolumn{2}{|c|}{ Stage- 2} & \multicolumn{2}{|c|}{ Stage- 3} & \multirow{2}{*}{$\begin{array}{c}\text { Mean } \\
(\mathbf{V x})\end{array}$} \\
\hline & & $\begin{array}{c}\text { Non } \\
\text { Infected }\end{array}$ & Infected & $\begin{array}{c}\text { Non } \\
\text { Infected }\end{array}$ & Infected & $\begin{array}{c}\text { Non } \\
\text { Infected }\end{array}$ & Infected & \\
\hline 1 & $\begin{array}{c}\text { G.Til-10 } \\
\text { root }\end{array}$ & 5.273 & 6.553 & 5.833 & 6.873 & 7.853 & 8.473 & 6.810 \\
\hline 2 & $\begin{array}{c}\text { G.Till-10 } \\
\text { leaf }\end{array}$ & 5.313 & 6.153 & 5.393 & 7.873 & 6.433 & 8.593 & 6.627 \\
\hline 3 & $\begin{array}{c}\text { G.Till-4 } \\
\text { root }\end{array}$ & 5.593 & 6.033 & 7.433 & 7.753 & 7.953 & 9.033 & 7.300 \\
\hline \multirow[t]{2}{*}{4} & $\begin{array}{c}\text { G.Till-4 } \\
\text { leaf }\end{array}$ & 5.773 & 6.203 & 6.993 & 7.793 & 7.933 & 8.983 & 7.280 \\
\hline & \multirow[t]{2}{*}{$\begin{array}{c}\text { Mean } \\
(\mathbf{S x}) \\
\end{array}$} & 5.488 & 6.236 & 6.413 & 7.573 & 7.543 & 8.771 & \\
\hline & & \multicolumn{3}{|c|}{ S.Em \pm} & \multicolumn{2}{|c|}{ CD at $5 \%$} & \multicolumn{2}{|c|}{ CV \% } \\
\hline & $\mathbf{V x}$ & \multicolumn{3}{|c|}{0.1226} & \multicolumn{2}{|c|}{0.3489} & \multirow{3}{*}{\multicolumn{2}{|c|}{7.42}} \\
\hline & Sx & \multicolumn{3}{|c|}{0.1501} & \multicolumn{2}{|c|}{0.4272} & & \\
\hline \multicolumn{2}{|c|}{ Vx X Sx } & \multicolumn{3}{|c|}{0.3002} & \multicolumn{2}{|c|}{0.8544} & & \\
\hline
\end{tabular}

\section{Guaiacol peroxidase (GPX)}

GPX activity of root and leaf tissue was significantly elevated from pre-infection stage (S1) to post-infection stage (S3) with respect to infected to non-infected tissue. The mean GPX activity was found highest in leaf tissue of susceptible G. Til-4 cultivar (138.038 U.mg ${ }^{-1}$ Fr.Wt.) followed by root tissue of susceptible $\mathrm{G}$. Til-4 cultivar (126.053 U.mg ${ }^{-1}$ Fr. Wt.). Among these cultivars, susceptible G. Til-4 cultivar showed 1.23 fold higher activity in their infected root tissue compared to non-infected root tissue followed by resistant G. Til-10 cultivar showed 1.06 fold higher activity in their infected root tissue compared to non-infected root tissue. During stage of post-infection (S3) infected root tissue of susceptible G. Til-4 cultivar showed 1.94 fold highest activity compared to S1 stage. In infected root tissue of resistant G. Til-10 cultivar showed 1.68 fold higher activity compared to S1 stage (Table 4). Overall, Guaiacol peroxidase activity significantly increased as increased the stage of disease development. An average, the root and leaf tissue of susceptible cultivar G.Til-4 shows significantly higher activities as compared to resistance cultivar G. Til-10. Lubaina and Murugan, (2012) studied Induction of plant defence against pathogen attack is regulated by a complex network of different signals. The activity of antioxidant enzymes increased in response to pathogen inoculation. Increase in activity of GPX was insignificant after $24 \mathrm{hr}$ post inoculation in the inoculated leaves. There was increase in GPX activity in root tissue of infected plant in the post infection stage from pre infection stage.

\section{Ascorbate peroxidase (APX)}

Ascorbate peroxidase (APX) activity was examined in root and leaf tissue of resistant and susceptible cultivars of sesame. The mean ascorbate peroxidase activity was found highest in root tissue of susceptible G. Til-4 (13.068 U.mg ${ }^{-1}$ Fr.Wt.) cultivar followed by leaf tissue of resistant G. Til-10 (3.465 U.mg ${ }^{-1}$ Fr.Wt.) cultivar (Table 5). The activity was increased from pre-infection to post-infection stage with higher elevated in infection tissue compared with non-infected tissue. Interaction effect 
between cultivar and disease development stage show significance difference. Among these cultivars, susceptible G. Til-4 (22.183 U.mg ${ }^{-1}$ Fr.Wt.) cultivar showed highest activity at $\mathrm{S} 3$ in root tissue followed by root tissue of resistant cultivar G. Til-10 (9.453 U.mg ${ }^{-1}$ Fr.Wt.) (Table 5). The activity of G. Til-4 was elevated 1.29 fold higher in infected root tissue to noninfected at S3 stage. Overall, Ascorbate peroxidase activity significantly increased as increased the stage of disease development. Ascorbate peroxidase activity of root and leaf tissue at three different stages of infection is higher in susceptible cultivar G. Til-4 as compared to resistant cultivar G. Til-10. Kandoliya and Vakharia (2015) reported variable response of Ascorbat peroxidase activity in chickpea infected with wilt pathogen. Kadkhodaie et al., (2013) showed that ascorbate peroxidase activity was increased with the level of infection increase. APX activity increased in post infection level as compared to control plant. There is a notable difference in susceptible and resistant genotype in APX enzyme activity. Furthermore, APX may play the role in-coordinating the expression of photo oxidative stress responsive genes APXs are involved not only in scavenging $\mathrm{H}_{2} \mathrm{O}_{2}$ but also in plant growth, development, lignifications, suberization, and cross-linking of cell wall compounds.

\section{Polyphenol oxidase (PPO)}

A progressive increase in the enzyme activity of the infected root and leaf tissue of resistant and susceptible cultivars were observed with the advancement of disease and growth of plants. During different infection stages, the mean effect showed highest activity in root tissue of susceptible cultivar G. Til-4 (7.300 U.mg ${ }^{-1}$ Fr.Wt.) compare with root of resistant cultivar G. Til-10 (6.810 U.mg ${ }^{-1}$ Fr.Wt.) (Table 6). Activity was significantly increased from preinfection stage (S1) to post-infection stage (S3) with respect to non-infected tissue to infected tissue. The combination between cultivar and disease development stages showed significant difference. The post-infection stage (S3) exhibited a continuous increase in the enzyme activities from the infection stage. Susceptible G. Til-4 cultivar showed 1.13 fold higher activity at S3 stage compared to non-infected root tissue, whereas resistant cultivar G. Til-10 showed 1.07 fold highest activity at compared to non-infected root tissue at S3 stage. Overall, an interaction between the varieties and disease development stages showed significantly higher PPO activities in susceptible as compared to resistant cultivar was found. Fallahpori et al., (2013) observed, polyphenol oxidase enzyme was assayed as a resistance mechanism in resistant and susceptible germplasm. Evaluation of polyphenol oxidase activity in resistant and susceptible germplasms in 2, 4, 6, 8, 10 and 12 days after inoculation with Fusarium oxysporum f. sp. Sesami showed that polyphenol oxidase enzyme activity increases in susceptible germplasm with highest level in 4 days after inoculation. In susceptible germplasm, enzyme activity was increased slightly in low quantity. Kandoliya and Vakharia (2013) also observed the same response in chickpea during infection of wilt pathogen. In conclusion the results show that polyphenol oxidase activity play probable role in induction of plant resistance against outbreak of plant pathogens.

In conclusion among the sesamum cultivars, root of resistant cultivar G. Til-10 showed the highest amount of total phenol content. The activity of ROS scavenging enzymes superoxide dismutase (SOD), Guaiacol peroxidase (GPX) and Ascorbate peroxidase (APX) was remained higher in infected root and leaf tissue of the susceptible cultivar G. Til-4 compared to resistant genotypes. In case of polyphenol oxidase, highest activity was noted in infected leaf and root tissue of susceptible (G. Til-4) cultivar. This indicates inherent response of cultivars against pathogen in response to infection process.

\section{References}

Akter, M.; Hossain, M.; Nahar, K.; Meah, M. and Hossain, M. (2007). Isolation and 
identification of phytophthora capsici and its mating type determination. Journal of agronomy for environment, 2: 89-92.

Bennet, M. (2011). Sesame seed: A Handbook for Farmers and Investors. 29/08/11. Available at

www.agmrc.org/media/cm/sesame_38F432 4EE52CB.pdf

Constantine, N. and Stanley, K.R. (1977). Superoxide dismutases. 1. Occurrence in higher plants. Plant Physiology. 59: 309314.

Costa, H.; Gallego, S.M. and Tomaro, M.L. 2002. Effect of UV-B radiation on antioxidant defense system in sunflower cotyledons. Plant Sceince. 62: 939-945.

Dubey, A. and Singh, T. (1999). Oospore contamination of and infection of phytophthora in sesame seeds. Journal of Indian Botanical Society, 78: 103-106.

Fallahpori, A.; Aminian, A. and Esmail, S. (2013). Evaluation of peroxidase activity in two resistant and susceptible sesame germplasms to fusarium damping-off caused by fusarium oxysporum f.sp. Sesami. Iraianian Journal of Plant Pathology, 49: 35-36.

Kadkhodaie, A.; Razmjoo, J. and Zahedi, M. (2013). Peroxidase, ascorbate peroxidase and catalase activities in drought sensitive, Intermediate and Resistance Sesame (Sesamum indicum L.) genotypes. International Journal of Agronomy and Plant Production, 4: 3012-3021.

Kandoliya U.K. and D. N. Vakharia (2013), Induced resistance and phenolic acid accumulation in biological control of chickpea wilt by Pseudomonas fluorescens. Asian J. Bio Sci. 8 (2):184-188.

Kandoliya U.K. and D. N. Vakharia (2015).
Ascorbic acid and ascorbate peroxidase based defence system induced by Pseudomonas fluorescens against wilt pathogen in chickpea. Internat. J. Plant Protec., 8(1): 86-92.

Lubina, A. and Murugan, K. (2012). Biochemical characterization of oxidative burst during Interaction between sesame (sesamum indicum 1.) in response to alternaria sesami. International Journal of Advanced Biological Research. 2: 86-91.

Malik, C.P. and Singh, M.B. 1980. In: Plant Enzymology and Histo-Enzymology. Kalyani Publications, New Delhi.

Nakano, Y. and Asada, K. 1981. Hydrogen peroxide is scavenged by ascorbate specific peroxidase in spinach chloroplasts. Plant Cell Physioogyl. 22: 868-880.

Patel N.J., Kandoliya U.K. and J.G Talati (2015) Induction of Phenol and Defence-Related Enzymes During Wilt (Fusarium udum Butler) Infestation in Pigeon Pea. International Journal of Curr. Microbiol. App. Sci, 4(2):291-299.

Rajab, R.; Rajan, S.; Sathees, L.; Harish, S.; Sunukumar, S.; Snadeep, B. and Murugan, K. (2009). Hypersensitive response of Sesamum prostratum Retz. elicitated by Fusarium oxysporum $f$. sesame (Schelt) Jacz Butler. Indian Journal of Experimental Biology, 47: 834-838.

Sharma, A.; Sharma, S.; Joshi, N. and Sharma P. (2011). Alteration in biochemical response in Sesamum indicum upon different plantpathogen interaction. Journal of Agriculture Science and Technology, 1: 68-75.

Van Rossun, M.N.P.C., Alberda, M. and Van Der Plas, L.H.W. 1997. Role of oxidative damage in tulip bulb scale micro propagation. Plant Sci., 130: 207-216.

\section{How to cite this article:}

Mori, D.S., U.K. Kandoliya, V.S. Bhatt, S.V. Patel and Golakiya, B.A. 2017. Evaluation of Phenolics and Antioxidant Enzyme Systems for Phytophthora Blight in Resistant and Susceptible Variety of Sesame (Sesamum Indicum L.). Int.J.Curr.Microbiol.App.Sci. 6(8): 2344-2352.

doi: https://doi.org/10.20546/ijcmas.2017.608.277 